DOI: $10.15290 /$ mwtusbwsdb.2019.03

\author{
ks. Andrzej Proniewski
}

\title{
ROLA I ZNACZENIE WYDZIAŁU TEOLOGICZNEGO USB W POWSTANIU SEMINARIUM W BIAEYMSTOKU
}

\section{Wstęp}

Problem relacji między Wydziałem Teologicznym Uniwersytetu Stefana Batorego w Wilnie a Seminarium Duchownym w Białymstoku to kwestia zamkniętej już historii, jak i aktualizującej się wciąż tradycji. Historii, bo punktem centralnym jawi się tu proces, z jednej strony, likwidacji kilkusetletniej uczelni (a wraz z nią Wydziału Teologicznego) przez sowieckie władze litewskie, z drugiej, uformowania najstarszej szkoły wyższej w Białymstoku, która wciąż odwołuje się - i słusznie - do „tradycji wileńskiej”.

Aby zrozumieć powyższe procesy sięgnąć należy najpierw do kwestii obecności w Wilnie, szczególnie w latach przedwojennych, zarówno Wydziału Teologicznego Uniwersytetu Stefana Batorego, jak i formacji tamtejszego duchowieństwa w ówcześnie istniejącym Seminarium Duchownym.

Kolejnym ważnym problemem jest sprawa geopolitycznej zawieruchy okresu międzywojnia, która zaowocowała nie tylko okrucieństwem II wojny światowej, ale i trwającymi do dziś konsekwencjami w postaci zmiany ustalonych po I wojnie światowej granic, przymusem przesiedlenia milionów ludzi, w końcu koniecznością wyboru pomiędzy wiernością wierze ojców, a więc zarówno ojczyźnie, jak i Tradycji Kościoła, a lojalnością wobec nowego, narzuconego kształtu ojczyzny i nowej władzy, zwanej, chyba na wyrost, „ludową i demokratyczną", która, najdelikatniej ujmując, dla wiary ojców zbyt wiele miejsca nie przewidywała.

W świetle tych informacji można zająć się tematem przymusowej, żmudnej translokacji wileńskiej organizacji kościelnej, a co za tym idzie, także Wydziału Teologicznego USB oraz wileńskiego Seminarium, do mieszczącego 
się około trzysta kilometrów na południowy zachód, liczącego wówczas ledwie nieco ponad 50 tys. mieszkańców Białegostoku¹.

Opisując rolę Wydziału Teologicznego USB w tworzeniu Seminarium Duchownego w Białymstoku nie możemy zapomnieć, że obie te instytucje to nie tylko struktura, ale przede wszystkim tworzący ją ludzie wraz ze swoimi losami, wykształceniem, umiejętnościami i przyzwyczajeniami. Historia przeto i biografie poszczególnych bohaterów omawianego zjawiska odgrywają tu rolę niebagatelną.

Źródła, do których należy się odwołać badając postawione zagadnienie, to głównie archiwalia zarówno o charakterze urzędowym, jak i prywatnym, zapisy różnego rodzaju wystąpień władz kościelnych i uczelnianych, listy osób związanych z powyższymi środowiskami. Istotną pomocą okazują się także opracowania biografii pracowników naukowych omawianych instytucji oraz te o charakterze bardziej ogólnym, pośród których należy podkreślić publikację ks. Jana Pankiewicza umieszczoną w jubileuszowej księdze poświęconej białostockiemu Seminarium z roku $1981^{2}$ oraz artykuł dotyczący obecności Wydziału Teologicznego USB w Białymstoku pióra ks. dr. Stanisława Hołodoka opublikowany w analogicznej księdze z roku $1995^{3}$.

Przedstawienie niniejsze podzielone zostało na kilka części. Odwołamy się do związków wileńskiego Seminarium z Wydziałem Teologicznym USB, do problemu translokacji obu jednostek naukowych, w końcu do dalszych losów tych instytucji w realiach powojennego Białegostoku i dziejów poszczególnych osób je tworzących o tyle, o ile miało to istotny wpływ na tworzące się Seminarium białostockie.

\section{Wilno. Seminarium i Wydział Teologiczny}

Nie ma tu konieczności wspominania szczegółowo dziejów obecności teologii w przestrzeni Uniwersytetu w Wilnie. Dość rzec, iż od momentu założenia w 1570 roku jezuickiego kolegium, które stało się kolebką przyszłego Uniwersytetu, w obrębie uczelni zawsze było miejsce dla nauk teologicznych. Gdy 7 lipca 1578 roku Stefan Batory podniósł wspomniane kolegium do

Dokładnie, według danych Urzędu Statystycznego, w 1946 r. liczba ta wynosiła 56,7 tys. mieszkańców. Źródło: www.bialystok.pl.pl/dla_mieszkancow/wschodzacy_bialystok/dane-statystyczne.html.

2 J. Pankiewicz, I. Dzieje, w: Archidiecezjalne Wyższe Seminarium Duchowne w Białymstoku 1945-1980 [dalej ArchWSD 1945-1980], red. E. Ozorowski, Białystok 1981, s. 11-35.

3 S. Hołodok, Wydział Teologiczny Uniwersytetu Stefana Batorego w Białymstoku (1945-1951), w: Archidiecezjalne Wyższe Seminarium Duchowne w Białymstoku 1945-1995. Ksiega jubileuszowa, Białystok 1995, s. 46-70. 
rangi Akademii, co potwierdzone zostało jeszcze bullą papieską Grzegorza XIII z 30 października 1579 roku, wśród Wydziałów znalazł się także Teologiczny. W późniejszych czasach, gdy w latach 1773-1781 Akademia przekształcała się w Szkołę Główną Wielkiego Księstwa Litewskiego i przechodziła pod zarząd Komisji Edukacji Narodowej, większość kadry stanowiło duchowieństwo, a w tzw. kolegium moralnym tejże szkoły funkcjonowały katedry zarówno prawa kościelnego, jak i teologii ${ }^{4}$. Gdy nadeszły czasy niewoli narodowej, uczelni w 1797 roku nadano nazwę Szkoła Główna Wileńska, zaś w 1803 roku Cesarski Uniwersytet Publiczny [Imperatorski Uniwersytet Publiczny]. Teologia znalazła się w fakultecie nauk moralnych i politycznych5. W tymże 1803 roku przy Uniwersytecie otwarto także Seminarium Główne dedykowane formacji przyszłego duchowieństwa.

Co prawda, w 1831 roku car nakazał z przyczyn politycznych likwidację Uniwersytetu Wileńskiego, ale teologiczne jednostki uniwersyteckie wraz z Seminarium Głównym, dwa lata później dały początek Rzymskokatolickiej Akademii Duchownej w Wilnie, która programem kształcenia objęła 60 studentów Seminarium wileńskiego oraz $40 \mathrm{z}$ innych diecezji metropolii wileńskiej i 7 alumnów obrządku ormiańskiego. W 1842 roku, po jej zamknięciu i przeniesieniu do Petersburga, narodziła się na nowo jako tamtejsza Akademia Duchowna 6 .

Kolejny etap interesującej nas historii rozpoczął się w roku 1919, gdy władze wolnej, po czasach zaborów, Polski podjęły decyzję o reaktywacji Uniwersytetu Wileńskiego im. Stefana Batorego. Za pozwoleniem papieża Benedykta XV, na prośbę biskupa (późniejszego błogosławionego) Jerzego Matulewicza, reaktywowano także Wydział Teologiczny, składający się z pokaźnej liczby dziewięciu katedr7.

W nowej rzeczywistości wileńskie środowisko kościelno-uniwersyteckie stanęło przed problemem bardziej szczegółowego zdefiniowania związków pomiędzy Wydziałem Teologicznym USB a Wyższym Seminarium Duchownym. Rządca wileńskiego Kościoła, wspomniany wyżej bp J. Matulewicz oparł się, między innymi na opinii biegłego w temacie ks. prof. Bronisława Żongołłowicza i postanowił, by obie jednostki zachowały swoją strukturę

S. Hołodok, op. cit., s. 46; I. Szybiak, Szkolnictwo Komisji Edukacji Narodowej w Wielkim Księstwie Litewskim, Wrocław 1973, s. 45-67, 148-181.

$5 \quad$ S. Hołodok, op. cit., s. 46; M. Kosman, Uniwersytet Wileński 1579-1979, Wrocław 1981, s. 3839; D. Beauvois, Szkolnictwo polskie na ziemiach litewsko-ruskich 1803-1832, t.1, Uniwersytet Wileński, Lublin 1991, s. 242-255.

6 S. Hołodok, op. cit., s. 47, T. Krahel, Zarys dziejów Archidiecezji Wileńskiej, „Studia Teologiczne. Białystok, Łomża, Drohiczyn” 5-6 (1987-1988), s. 47.

$7 \quad$ S. Hołodok, op. cit., s. 47; M. Kosman, Uniwersytet Wileński..., s. 59; B. Żongołłowicz, Wydział Teologiczny Uniwersytetu Stefana Batorego w okresie 1919-1920 r., Wilno 1931, s. 27-31. 
i wzajemną niezależność organizacyjną. Na tym założeniu oparto wspólny projekt studiów teologicznych i relacji pomiędzy obiema instytucjami. Wynikiem jego opracowania przede wszystkim przez bp. J. Matulewicza i ks. prof. Ignacego Świrskiego, było przesłanie dokumentu do Stolicy Apostolskiej z prośbą o aprobatę. Otrzymano ją 28 września 1925 roku. Na mocy zatwierdzonej umowy Wyższe Seminarium Duchowne w Wilnie zostało włączone do Wydziału Teologicznego USB, zaś klerycy stawali się również studentami Uniwersytetu. Seminarium, choć włączone w struktury uniwersyteckie, nie zostało jednak przez nie wchłonięte - wykłady dla alumnów miały być prowadzone w budynku Seminarium, choć przez wykładowców uniwersyteckich, jednak bez obecności osób świeckich. Takie rozwiązanie stworzyło szansę na podniesienie poziomu intelektualnego duchowieństwa, równocześnie nie burząc toku formacji duchowej właściwej dla struktur seminaryjnych. Mianowany w 1926 roku nowy Metropolita Wileński, abp Romuald Jałbrzykowski, podjęte rozwiązania określił jako „moralne, pożądane i pożyteczne".

We wspomnianym momencie dziejów nikt spośród bohaterów powyższych wydarzeń nie zdawał sobie sprawy z tego, że za kilkanaście lat wypracowany model współpracy wydziałowo-seminaryjnej stanie się wzorem dla mających rozpocząć się w przyszłości studiów teologicznych w Białymstoku, a wspomnianemu abp. R. Jałbrzykowskiemu przyjdzie ten model przenieść do tego dość odległego miasta i w nowe, powojenne, socjalistyczne realia.

\section{Z Wilna do Białegostoku. Wojenna zawierucha i przymusowa przeprowadzka}

Druga wojna światowa przyniosła ze sobą konieczność całkowitej zmiany w obrębie nie tylko studiów teologii w Wilnie, ale i całej struktury tak Kościoła wileńskiego, jak i tamtejszego środowiska uczelnianego. Uniwersytet, choć nieprześladowany przez władze sowieckie po aneksji wschodnich terytoriów Rzeczypospolitej 17 września 1939 roku, jednak został zamknięty w wyniku decyzji władz litewskich, które nie mogły w nowych realiach znieść na swym terytorium tak znamienitej instytucji o polskich korzeniach i z polskim, widzianym już jako „obcy” językiem nauczania ${ }^{9}$. W związku z tą decyzją zarówno cały Uniwersytet, jak i Wydział Teologiczny, podjął kontynuację studiów w ukryciu. Studia teologiczne kontynuowano w Seminarium Duchownym,

S. Hołodok, op. cit., s. 47; B. Żongołłowicz, Wydział Teologiczny..., s.23.

S. Hołodok, op. cit., s. 48. Decyzją z 11 XII 1939 r. określono jako dzień zamknięcia uczelni 15 XII $1939 \mathrm{r}$. 
odbywały się tam zajęcia, a klerycy tworzyli prace magisterskie ${ }^{10}$. Trwało to jednak zaledwie dwa i pół roku.

Punktem przełomowym okazało się aresztowanie zarówno profesorów, jak i studentów teologii 3 marca 1942 roku. Po kolejnych dwóch latach, w roku 1944, wznowiono wykłady w Seminarium, jak i na Wydziale Teologicznym. Jednak nie na długo. 20 lutego 1945 roku litewskie władze zmusiły pracowników naukowych i studentów do opuszczenia Wilna i przeniesienia się w ramach tzw. repatriacji na terytorium Polski ${ }^{11}$. Wileński Uniwersytet Stefana Batorego znalazł się w ten sposób na nowym miejscu. Większość znakomitej, choć uszczuplonej przez trudne czasy, kadry jako kierunek docelowy wybrała Toruń, gdzie wniosła znaczący wkład w tworzenie dzisiejszego Uniwersytetu Mikołaja Kopernika, zaś związane przynależnością kościelną struktury Wydziału Teologicznego, zatem także i Seminarium Duchowne, jako swoje locum vivendi wybrało Białystok, budując w ten sposób fundament pod dzisiejsze Archidiecezjalne Wyższe Seminarium Duchowne.

\section{„Wilno w Białymstoku”. Instytucje teologiczne}

Omówione wyżej zjawiska - o niebagatelnym znaczeniu dla powstania i takiego a nie innego kształtu białostockiego Seminarium - znalazły swoje ukoronowanie w powojennych, trwających kilka lat, aż do zamknięcia Wydziału Teologicznego, wspólnych, wydziałowo-seminaryjnych dziejach białostockich studiów teologicznych. Warto przeto $\mathrm{w}$ tym miejscu omówić wpływ na kształtowanie nowej rzeczywistości samych instytucji, by w następnym punkcie przejść do części biograficznej i kwestii wpływu personalnego osób te instytucje tworzących.

Po decyzji władz państwowych z 20 lutego 1945 roku o repatriacji pracowników i studentów polskich instytucji teologicznych, niezwłocznie, pod koniec tego miesiąca abp R. Jałbrzykowski odbył naradę z księżmi profesorami i podjął decyzję o przeniesieniu Seminarium Duchownego do Białegostoku. Niebawem, w początkach marca 1945 roku, zlecił prefektowi Seminarium, ks. dr. Aleksandrowi Mościckiemu i prokuratorowi, ks. Janowi Krassowskiemu wyjazd do Białegostoku oraz zorganizowanie wraz z białostockim dziekanem, ks. Aleksandrem Chodyką, miejsca dla przyszłego Seminarium. W tymże miesiącu i to już trzeciego dnia pierwsi polscy alumni wyjechali z Wilna do Polski w ramach piątego, tzw. nauczycielskiego, transportu

10 S. Hołodok, op. cit., s. 48; Warto skorzystać z pracy magisterskiej: R. Kułak, Wydział Teologiczny Uniwersytetu Stefana Batorego i Metropolitalne Wyższe Seminarium Duchowne w Wilnie w czasie II wojny światowej, Lublin 1986, mps.

11 J. Pankiewicz, Dzieje..., s. 11. 
repatriacyjnego ${ }^{12}$. Już 7 marca większość zameldowała się u ks. A. Chodyki, który przyjął ich tymczasowo na plebanii, a potem rozlokował po wybranych parafiach aż do momentu zorganizowania miejsca dla Seminarium.

Rychło, 24 marca, przybyli do Białegostoku wspomniani księża A. Mościcki i J. Krassowski. Według ustnych relacji świadków tamtych wydarzeń pod uwagę brano kilka budynków w mieście i poza jego granicami, jak plebania parafii św. Rocha, kamienica przy ul. Warszawskiej nr 9 czy budynki klasztorne w Supraślu ${ }^{13}$. W końcu Seminarium siedzibę swą znalazło w gmachu Braci Sług Najświętszej Maryi Panny i św. Franciszka przy ul. Słonimskiej 8. Gdy 30 kwietnia 1945 roku „transportem uniwersyteckim” przybędzie grono profesorów, odbędzie się pierwsze posiedzenie grona wykładowców, czyli, jak to wciąż nazywamy, pierwsza sesja profesorska. Na niej to postanowiono, że zajęcia seminaryjne rozpoczną się 8 maja 1945 roku $^{14}$.

Na uwagę zwraca fakt, że wspomniani profesorowie, którzy przyjechali wówczas do Polski, to zarówno profesorowie Wydziału Teologicznego USB, jak i Seminarium Duchownego. Wydarzenie to mówi nam bardzo wiele. Oto tworzy się, tak naprawdę, białostockie Seminarium, choć wspomniana sesja to narada wykładowców Wydziału Teologicznego USB w Wilnie, a równocześnie wciąż wileńskiego Wyższego Seminarium Duchownego, jednak już w Białymstoku. Jak podkreślają historycy tematu, „wraz z początkiem zajęć w Seminarium Duchownym w Białymstoku rozpoczęto równocześnie intensywne starania o legalizację Wydziału Teologicznego, który przymusowo znalazł się w nowych granicach Polski”" ${ }^{15}$.

Możemy w powyższych zjawiskach wyodrębnić dwie oddzielne instytucje, choć złączone faktem przynależności kościelnej, i dwie przenikające się wzajemnie oraz uzupełniające historie. W Białymstoku zaczyna swą działalność Wyższe Seminarium Duchowne - wileńskie, ale już białostockie. Z rozmów ze świadkami tamtych wydarzeń wynika jasno, że wśród przybyłych do Białegostoku repatriantów trwało, i to przez kilka kolejnych lat, przekonanie o przejściowości takiego stanu rzeczy i o tym, że nadejdzie „za jakiś czas" moment powrotu do wileńskiej rzeczywistości. Takiego momentu nikt z tamtych ludzi już nie doczekał. Do 5 czerwca 1991 roku $^{16}$ pozostały w granicach Polski fragment Archidiecezji Wileńskiej stanowił tzw. Archidiecezję

12 J. Pankiewicz, Dzieje..., s. 14.

13 Ibidem, s. 14.

14 Archiwum Archidiecezji Białostockiej, Protokoły posiedzeń Rady Wydziału Teologicznego USB i profesorów Wileńskiego Seminarium Duchownego (1944-1955); S. Hołodok, op. cit., s. 49.

15 S. Hołodok, op. cit., s. 49.

16 W tym dniu miała miejsce w Białymstoku wizyta Papieża Jana Pawła II, który ogłosił wówczas ustanowienie diecezji białostockiej. Rok później, bullą Totus tuus Poloniae populus 
w Białymstoku i był rządzony przez administratorów apostolskich. Po tym roku (choć w rzeczywistości już dużo wcześniej) mówimy o Kościele białostockim i o Seminarium Duchownym nie tylko w Białymstoku, ale realnie białostockim, a jego pierwsi profesorowie byli równocześnie pracownikami Wydziału Teologicznego USB - i Seminarium.

W odniesieniu do historii uniwersyteckiej Wydział Teologiczny funkcjonował w Białymstoku, miał swoją strukturę, prowadził pracę i starał się o umiejscowienie w nowej rzeczywistości. Świadczą o tym choćby listy pisane do instytucji państwowych, jak na przykład pismo ks. prof. Ignacego Świrskiego, prodziekana Wydziału, który informował 4 czerwca 1945 roku ówczesnego ministra oświaty, że Wydział Teologiczny USB znalazł się w Białymstoku i prowadzi tu swoją działalnośćc ${ }^{17}$. Wydział Teologiczny USB, po żmudnych zmaganiach, zakończył swoje istnienie decyzją władz w latach 1948-194918. Jego skład personalny podano po raz ostatni w spisie duchowieństwa Archidiecezji Wileńskiej w Białymstoku z roku 1949 ${ }^{19}$. Przystanią dla nieoficjalnej już działalności Wydziału, która trwała do roku 1951, stały się mury Seminarium w Białymstoku. Świadczą o tym choćby zapisy protokolarne sesji profesorskich. Po raz ostatni wspólna sesja Rady Wydziału Teologicznego USB i profesorów Wyższego Seminarium Duchownego miała miejsce 18 grudnia 1951 roku, kolejne, zaczynając od 29 lutego 1952 roku to już sesje „tylko” profesorów Seminarium Duchownego w Białymstoku²0.

Swoisty wymiar związku między Wydziałem Teologicznym USB a Seminarium stanowi fakt osiągania stopni naukowych przez absolwentów i pracowników naukowych nie tylko wileńskiego, ale także już białostockiego Seminarium. Zaliczyć tu należy niezatwierdzone, co prawda, ale powtórzone później na Wydziale Teologicznym Uniwersytetu Warszawskiego kolokwia habilitacyjne ks. Walentego Urmanowicza i ks. Władysława Suszyńskiego oraz magisteria absolwentów osiadłego w Białymstoku Seminarium: ks. Henryka Brzozowskiego (1946), ks. Edwarda Kisiela, późniejszego pierwszego Arcybiskupa Metropolity Białostockiego (1946), ks. Czesława Kałużyńskiego (1947), ks. Adama Bakury (1948), ks. Stanisława Więckiewicza (1948) i ks. Mieczysława Stopczyńskiego (1949).

została ona podniesiona do rangi Archidiecezji i stała się centrum nowej kościelnej metropolii białostockiej.

17 Archiwum Archidiecezji Białostockiej, Teczka: Sprawy Wydziału USB po przeniesieniu do Białegostoku, pismo ks. I. Świrskiego do ministra WRiOP w Warszawie, Białystok, nr 1/45, 4 VI 1945 r. Obraz zmagań o legalizację Wydziału Teologicznego USB w Białymstoku i jego dzieje przedstawia wspominany już wielokrotnie artykuł: S. Hołodok, op. cit., s. 49-57.

18 S. Hołodok, op. cit., s. 56.

19 Calendarium liturgicum pro A.D. 1949 ad usum Archidioecesis, Białystok 1949, s. 1-2.

20 Archiwum Archidiecezji Białostockiej, Protokoły 1945-1955. 
Można postawić pytanie: czy to Wydział znalazł się w Seminarium, czy Seminarium powstało dzięki Wydziałowi? Tak, jak przenikają się dwie historie, tak można udzielić dwóch odpowiedzi i obie będą prawdziwe. W naszym jednak przypadku możemy zdecydowanie stwierdzić, iż to profesorowie oraz repatriowani studenci Wydziału Teologicznego Uniwersytetu Stefana Batorego stanowili fundament powstałego w Białymstoku Archidiecezjalnego Wyższego Seminarium Duchownego.

Oczywiste jest, że zarówno Wydział, jak i Seminarium, to przede wszystkim konkretne osoby. Warto przyjrzeć się biografiom przynajmniej niektórych z nich.

\section{„Wilno w Białymstoku”. Osoby}

Wileńscy wykładowcy przybyli do Białegostoku 30 kwietnia 1945 roku. W skład uniwersyteckiej ekipy weszli wówczas: dziekan Wydziału - ks. Michał Klepacz, prodziekan - ks. Ignacy Świrski, mianowany przez abp. R. Jałbrzykowskiego rektorem Seminarium, ks. Paweł Nowicki, ks. Antoni Pawłowski, ks. Walenty Urmanowicz i ks. Czesław Falkowski. To oni nadali kształt białostockiemu Seminarium. Pokrótce przyjrzyjmy się ich biografiom.

Ksiądz prof. dr Michał Klepacz (1893-1967) ${ }^{21}$ - pochodzący z Warszawy a wyświęcony w Kielcach kapłan, absolwent Akademii Duchownej w Petersburgu i KUL, profesor nadzwyczajny filozofii chrześcijańskiej i dziekan Wydziału Teologicznego USB. Wykłady prowadził w latach 1945-1947 z następujących przedmiotów: teodycea, apologetyka, pedagogika, ontologia i teologia dogmatyczna. W 1946 roku został mianowany biskupem łódzkim. Zachował tytuł profesora honorowego, a w 1947 otrzymał doktorat honoris causa Wydziału.

Ksiądz prof. dr Ignacy Świrski (1885-1968) ${ }^{22}$ - urodzony w Ellernie k. Dyneburga kapłan Archidiecezji Mohylewskiej, absolwent Uniwersytetu Gregoriańskiego w Rzymie, gdzie obronił dwa doktoraty: $\mathrm{z}$ zakresu filozofii i teologii. Od 1921 profesor nadzwyczajny, a od 1937 profesor zwyczajny teologii moralnej na Wydziale Teologicznym USB. W Białymstoku od 1945 roku prodziekan Wydziału i pierwszy rektor Seminarium Duchownego, w którym prowadził wykłady z teologii moralnej i szczegółowej. Od 1946 biskup diecezji siedleckiej i profesor honorowy Wydziału Teologicznego USB.

\footnotetext{
${ }^{21}$ Szerzej na jego temat: T. Krahel, Klepacz Michał (1893-1967), Słownik polskich teologów katolickich, red. H.E. Wyczawski, L. Grzebień, Warszawa 1981-1983 [dalej SPTK], VII, 77-78; ArchWSD 1945-1980, s. 77-79.

22 E. Ozorowski, Świrski Ignacy (1885-1968), SPTK, VII, 302-304, ArchWSD 1945-1980, s. 129-133.
} 
Ksiądz prof. dr hab. Paweł Nowicki (1888-1980)23 - urodzony w Wałczu, na Pomorzu, absolwent Seminarium w Pelplinie, kapłan diecezji chełmińskiej, doktoryzowany we Fryburgu w zakresie filologii (lingwistyka semicka) i w Wilnie, w zakresie teologii. Habilitowany w Warszawie, w 1934 roku został profesorem nadzwyczajnym wileńskiego Wydziału Teologicznego. Później, od roku 1948 profesor nauk biblijnych na Wydziale Teologicznym Uniwersytetu Warszawskiego i biblista w ATK. Był poliglotą i autorem podręczników języków orientalnych. W białostockim Seminarium, w latach 1945-1948 prowadził zajęcia ze Wstępu do Pisma Świętego, z Nowego Testamentu, archeologii biblijnej oraz języków: greckiego, hebrajskiego i łaciny.

Ksiądz prof. dr hab. Antoni Pawłowski (1903-1968)24 - pochodzący z Końskich, kapłan warszawski, absolwent tamtejszego Seminarium i studiów doktorskich w UW. Habilitowany tamże i mianowany w 1939 roku profesorem nadzwyczajnym w Wilnie. Chociaż już w 1945 roku wyjechał do Warszawy, gdzie był kierownikiem katedry dogmatyki na Wydziale Teologicznym UW i profesorem zwyczajnym, to jednak od przyjazdu z Wilna zapisał się jako białostocki wykładowca teologii dogmatycznej i fundamentalnej.

Kolejny z wymienionych - ks. prof. dr hab. Walenty Urmanowicz (18981969 ${ }^{25}$ pochodzący z Nowowilejki kapłan diecezji wileńskiej, absolwent tamtejszego Seminarium, potem zaś takich uczelni, jak KUL, Instytut Katolicki w Paryżu, doktoryzowany we Fryburgu Badeńskim, od 1945 roku, zastępca profesora na Wydziale Teologicznym USB i wykładowca teologii moralnej, etyki, logiki, krytyki poznania, a nawet śpiewu i socjologii w Seminarium w Białymstoku. Habilitowany w 1946 roku na Wydziale Teologicznym USB (tej habilitacji nie uznało Ministerstwo Oświaty) i w roku 1947 na Wydziale Teologicznym UW. Mianowany docentem - zastępcą profesora USB, a potem (od 1954) profesor nadzwyczajny teologii moralnej w ATK.

Podany spis pierwszej grupy wileńskich profesorów, którzy przyjechali do Białegostoku zamyka ks. prof. dr Czesław Falkowski (1887-1969) ${ }^{26}$, absolwent Seminarium Duchownego w Petersburgu, doktoryzowany na Uniwersytecie w Innsbrucku, kapłan Archidiecezji Mohylewskiej. W swej historii uniwersyteckie szlify zdobywał jako profesor Seminarium w Petersburgu, profesor

23 T. Krahel, Nowicki Paweł, SPTK, VI; Idem, Ksiądz profesor Paweł Nowicki, „W Służbie Miłosierdzia”, 11/2009, s. 14.

24 E. Ozorowski, Pawłowski Antoni (1903-1968), SPTK, VI, 625-629.

25 T. Krahel, Ksiądz Profesor Walenty Urmanowicz, „W Służbie Miłosierdzia”, 3/2010, s. 14; J. Pryszmont, Ks. prof. dr Walenty Urmanowicz (1898-1969), „Collectanea Theologica”, 40 (1970), nr 2, s. 163-165; E. Wyczawski, Urmanowicz Walenty (1898-1969), SPTK, VII, 355-356.

26 T. Krahel, Biskup Czesław Falkowski. Rektor Uniwersytetu Stefana Batorego, „W Służbie Miłosierdzia”, 8/2009, s. 14; E. Ozorowski, Falkowski Czesław (1887-1969), SPTK, V, 354-356. 
Akademii Duchownej, profesor historii Kościoła i jeden z organizatorów Katolickiego Uniwersytetu Lubelskiego, profesor Wydziału Teologicznego USB. $\mathrm{Z}$ wymienianego tu grona osiągnął najwyższe stanowiska, pełniąc po kolei funkcje: w latach 1921-1923 prodziekana Wydziału Teologicznego, w latach 1923-1924 i 1926-1928 dziekana, rektora całej wileńskiej uczelni w latach 1928-1930, a następnie przez dwa lata jej prorektora. W białostockim Seminarium prowadził wykłady $\mathrm{z}$ historii Kościoła, patrologii i homiletyki, a od 1947 pełnił też funkcję dziekana Wydziału. Etap białostocki zakończył w 1949 roku, kiedy to został mianowany biskupem łomżyńskim.

Wspomnieliśmy tu kilku profesorów, ale lista wileńsko-białostockich wykładowców bynajmniej nie kończy się w tym miejscu. Do grona najwcześniej przybyłych do Białegostoku pracowników USB z czasem dołączyło jeszcze kilku przedstawicieli. Warto ich tutaj wspomnieć.

Ksiądz dr hab. Władysław Suszyński (1898-1968) ${ }^{27}$ - pochodzący z Janowa k. Sokółki absolwent wileńskiego Seminarium, teologii w KUL, doktoryzowany w Paryżu w zakresie filozofii, od 1928 roku wykładowca filozofii i prawa w wileńskim Seminarium, od 1930 roku zastępca profesora filozofii chrześcijańskiej Wydziału Teologicznego USB. W realiach białostockich nadal zastępca profesora filozofii WT USB, nadto wykładowca seminaryjny takich przedmiotów jak: kosmologia, teodycea, historia filozofii, prawo kanoniczne, psychologia, metafizyka, od 1946 roku doktor habilitowany (po nieuznanym przez ministra oświaty przewodzie habilitacyjnym Wydziału Teologicznego, powtórzył habilitację na Wydziale Teologicznym UW), rektor Seminarium, a od 1948 roku biskup sufragan abp. R. Jałbrzykowskiego i administrator Archidiecezji w Białymstoku.

Ksiądz mgr Antoni Cichoński (1888-1975)28 wracając do Białegostoku po wieloletniej tułaczce, wracał do siebie. Urodzony w Białymstoku, odbył studia w Seminarium Duchownym w Wilnie i Akademii Duchownej w Petersburgu. Profesorem Seminarium został w 1913 roku. Od 1925 roku pełnił też funkcję zastępcy profesora Wydziału Teologicznego USB. W Białymstoku zapisał się jako pracownik Wydziału i Seminarium, gdzie prowadził zajęcia $z$ Pisma Świętego, archeologii biblijnej i historii sztuki kościelnej i sprawował urząd rektora w latach 1968-1972.

27 R. Kotkowicz, Ksiądz biskup Władysław Suszyński (1898-1968), „Wiadomości Kościelne Archidiecezji w Białymstoku" 4 (1978), n. 4, s. 40-48; T. Krahel, Biskup Władysław Suszyński, „W Służbie Miłosierdzia”, 3/2008, s. 14.

28 T. Krahel, Ksiądz infułat Antoni Cichoński, „W Służbie Miłosierdzia”, 7/2007, s. 14; S. Piotrowski, Ks. infułat Antoni Cichoński, „Wiadomości Kościelne Archidiecezji w Białymstoku” 13 (1987), n. 4, s. 114-123. 
Ksiądz dr hab. Witold Pietkun (1911-1981) ${ }^{29}$ to kolejna interesująca postać. Urodzony w Ikaźni, na Wileńszczyźnie, ukończył Seminarium w Wilnie i doktoryzował się na tamtejszym Wydziale Teologicznym, pełnił także funkcję asystenta na tymże Wydziale. W Białymstoku pracował jako starszy asystent. W tym czasie przeprowadził też przewód habilitacyjny na Wydziale Teologicznym UW i prowadził zajęcia w Seminarium, jak pozostali wykładowcy, także z wielu przedmiotów: historii filozofii, epistemologii, ontologii, teodycei, teologii fundamentalnej, ale także łaciny oraz śpiewu.

Na koniec wypada nam przywołać postać najbardziej chyba znaną spośród tych, które możemy nazwać „łącznikami” pomiędzy Wilnem a Białymstokiem. Mowa o ks. dr. hab. Michale Sopoćko (1888-1975) $)^{30}$. Absolwent Seminarium w Wilnie i Uniwersytetu Warszawskiego oraz Państwowego Instytutu Pedagogicznego w Warszawie. W stolicy, konkretnie na Wydziale Teologicznym UW, zdobył też tytuł doktora. W 1927 roku objął funkcję ojca duchownego alumnów wileńskich. Na Wydziale Teologicznym USB, w którym pracował jako zastępca profesora już od 1928 roku (w katedrze teologii pastoralnej) obronił w 1934 roku habilitację. Gdy znalazł się w Białymstoku był już rok 1947. Wówczas to podjął pracę zarówno w Seminarium, jak i na Wydziale Teologicznym. Prowadził wykłady z teologii pastoralnej, pedagogiki, katechetyki i homiletyki. Na emeryturę przeszedł w 1962 roku. To, co czyni jego biografię szczególną nie zamyka się jedynie w ramach relacji uczelnianych. Znany jako Apostoł Bożego Miłosierdzia ks. Michał został 28 września 2008 beatyfikowany w Sanktuarium Miłosierdzia Bożego w Białymstoku, gdzie dziś spoczywają jego relikwie, będące celem licznych pielgrzymek z kraju i zza granicy.

\section{Zakończenie}

Postać ks. Sopoćki, celowo wymieniona na końcu tego opracowania, kieruje nas ku faktowi związanemu głęboko z postawionym w tytule procesem powstawania białostockiego Seminarium Duchownego. Rzeczywistość Wydziału Teologicznego USB i Seminarium w Białymstoku, to dwie rzeczywistości symbiotyczne. Być może, że gdyby nie przynależność kościelna pracowników Wydziału, także oni powędrowaliby do Torunia lub innych ośrodków, a historia początków białostockiego Seminarium wyglądałaby zupełnie

29 T. Krahel, Ksiądz Witold Pietkun, „W Służbie Miłosierdzia” 5/2006, s. 14.

30 Ks. Michał Sopoćko doczekał się na swój temat obszernej literatury, której tu nie sposób wymienić. Na uwagę zasługuje przede wszystkim publikacja bp. Henryka Ciereszki, w której można też odnaleźć dalszą bibliografię: H. Ciereszko, Życie i działalność Księdza Michała Sopoćki (1888-1975). Petna biografia apostoła Miłosierdzia Bożego, Kraków 2006. 
inaczej. Tak jednak się nie stało, a Wydział i osiadłe w Białymstoku wileńskie Seminarium stworzyły współuzupełniającą się hybrydę, która legła u podstaw istniejącego już kilkadziesiąt lat Seminarium - w całym tego słowa znaczeniu - białostockiego.

Jak wskazuje nazwa Seminarium to miejsce zasiewu (seminare = siać). Tak złożyło się, że „sianiem” w tym konkretnym Seminarium zajęli się pracownicy Wydziału Teologicznego USB. A siali oni nie tylko wiedzę, kształcąc pierwsze pokolenia białostockich kapłanów, ale także duchową mądrość, świętość (jak wspomniany ks. M. Sopoćko, czy ks. I. Świrski, którego proces beatyfikacyjny jest w toku). Siali także kulturę. Do dziś wielu starszych absolwentów Seminarium wspomina dawnych profesorów jako ludzi z wielka klasą. Owocem tego zasiewu, w różnych jego wymiarach, są pokolenia księży, których postawą i dokonaniami można się poszczycić.

Pewnym echem tamtych czasów są odwołania do „tradycji wileńskiej”, przeszczepione $z$ Wilna zwyczaje nazywania cenzorem przewodniczącego samorządu kleryckiego czy prokuratorem dyrektora administracyjnego Seminarium. Ale na tym łączność się nie kończy. To bowiem, co zostało wówczas zasiane, może nie w każdym w sposób w pełni uświadomiony, trwa i jest dla nas powodem nie tylko do wspomnień, ale także do chlubienia się pięknym i wciąż żywym źródłem, z którego wypłynęła rzeka naszej historii.

\section{Bibliografia}

Archiwum Archidiecezji Białostockiej, Protokoły posiedzeń Rady Wydziału Teologicznego USB i profesorów Wileńskiego Seminarium Duchownego (1944-1955).

Beauvois D., Szkolnictwo polskie na ziemiach litewsko-ruskich 1803-1832, t. 1, Uniwersytet Wileński, Lublin 1991.

Calendarium liturgicum pro A.D. 1949 ad usum Archidioecesis, Białystok 1949, s. 1-2.

Ciereszko H., Życie i działalność Księdza Michała Sopoćki (1888-1975). Pełna biografia apostoła Miłosierdzia Bożego, Kraków 2006.

Hołodok S., Wydział Teologiczny Uniwersytetu Stefana Batorego w Białymstoku (19451951), w: Archidiecezjalne Wyższe Seminarium Duchowne w Biatymstoku 19451995. Ksiega jubileuszowa, Białystok 1995, s. 46-70.

Kosman M., Uniwersytet Wileński 1579-1979, Wrocław 1981.

Kotkowicz R., Ksiądz biskup Władysław Suszyński (1898-1968), „Wiadomości Kościelne Archidiecezji w Białymstoku" 4 (1978), n. 4, s. 40-48.

Krahel T., Biskup Czesław Falkowski. Rektor Uniwersytetu Stefana Batorego, „W Służbie Miłosierdzia", 8/2009, s. 14.

Krahel T., Biskup Władysław Suszyński, „W Służbie Miłosierdzia”, 3/2008, s. 14. 
Krahel T., Klepacz Michał (1893-1967), w: Słownik polskich teologów katolickich, red. H.E. Wyczawski, L. Grzebień, Warszawa 1981-1983, VII, 77-78.

Krahel T., Ksiądz infułat Antoni Cichoński, „W Służbie Miłosierdzia”, 7/2007, s. 14.

Krahel T., Ksiądz profesor Paweł Nowicki, „W Służbie Miłosierdzia”, 11/2009, s. 14.

Krahel T., Ksiądz Profesor Walenty Urmanowicz, „W Służbie Miłosierdzia”, 3/2010, s. 14

Krahel T., Ksiądz Witold Pietkun, „W Służbie Miłosierdzia” 5/2006, s. 14.

Krahel T., Nowicki Paweł, w: Słownik polskich teologów katolickich, red. H.E. Wyczawski, L. Grzebień, Warszawa 1981-1983, VI.

Krahel T., Zarys dziejów Archidiecezji Wileńskiej, „Studia Teologiczne. Białystok, Łomża, Drohiczyn" 5-6 (1987-1988).

Kułak R., Wydział Teologiczny Uniwersytetu Stefana Batorego i Metropolitalne Wyższe Seminarium Duchowne w Wilnie w czasie II wojny światowej, Lublin 1986, mps.

Ozorowski E., Falkowski Czesław (1887-1969), w: Słownik polskich teologów katolickich, red. H.E. Wyczawski, L. Grzebień, Warszawa 1981-1983, V.

Ozorowski E., Pawłowski Antoni (1903-1968), w: Słownik polskich teologów katolickich, red. H.E. Wyczawski, L. Grzebień, Warszawa 1981-1983, VI.

Ozorowski E., Świrski Ignacy (1885-1968), w: Słownik polskich teologów katolickich, red. H.E. Wyczawski, L. Grzebień, Warszawa 1981-1983, VII, 302-304.

Pankiewicz J., I. Dzieje, w:.Archidiecezjalne Wyższe Seminarium Duchowne w Białymstoku 1945-1980, red. E. Ozorowski, Białystok 1981, s. 11-35.

Piotrowski S., Ks. infułat Antoni Cichoński, „Wiadomości Kościelne Archidiecezji w Białymstoku", 13 (1987), n. 4, s. 114-123.

Pryszmont J., Ks. prof. dr Walenty Urmanowicz (1898-1969), „Collectanea Theologica”, 40 (1970), nr 2.

Szybiak I., Szkolnictwo Komisji Edukacji Narodowej w Wielkim Księstwie Litewskim, Wrocław 1973.

www.bialystok.pl.pl/dla_mieszkancow/wschodzacy_bialystok/dane-statystyczne.html.

Wyczawski E., Urmanowicz Walenty (1898-1969), w: Słownik polskich teologów katolickich, red. H.E. Wyczawski, L. Grzebień, Warszawa 1981-1983, VII.

Żongołłowicz B., Wydział Teologiczny Uniwersytetu Stefana Batorego w okresie 19191920 r., Wilno 1931. 